\title{
Identification of native and hybrid elms in Spain using isozyme gene markers
}

\author{
MIGUEL ÁNGEL COGOLLUDO-AGUSTÍN†, DOLORES AGÚNDEZ \& \& LUIS GIL*† \\ †Unidad de Anatomí, Fisiología y Mejora Genética, Dpto. de Silvopascicultura, E.T.S. de Ingenieros de Montes, \\ U.P.M., Ciudad Universitaria, 28040-Madrid, Spain and $\$$ CIFOR-INIA, Dpto. de Mejora Genética y Biotecnología, \\ Ctra. de la Coruña km. 7, 28040-Madrid, Spain
}

\begin{abstract}
Two elm taxa occur naturally in the Iberian Peninsula: the Field elm (Ulmus minor) and the Wych elm (U. glabra). In addition, a third taxon, the foreign Siberian elm (U. pumila), was probably introduced in the 16th century as an ornamental tree and has spread spontaneously throughout the Peninsula. The natural hybridization between $U$. minor and $U$. pumila produced new individuals whose morphological traits appear to be mixed. Ulmus pumila, as well as its hybrids, has a high resistance to Dutch elm disease (DED). For this reason, it is commonly used in breeding programmes. Extensive hybridization and the high mortality produced by the last DED epidemic have endangered the conservation of the native elm. In this study, isozyme analyses are used to characterize the taxa $U$. minor and U. pumila. Siberian elms from Spain and China are compared with the native U. minor. Siberian elm produces isozyme patterns that completely differentiate it from $U$. minor. Three loci are completely different between the species: $6 \operatorname{Pg} d 2, M d h 1$ and $\operatorname{Pr} x 2$. Isozyme markers can also be used to distinguish native elms from the hybrids that have evolved for generations.
\end{abstract}

Keywords: genetic conservation, genetic diversity, hybridization, isozymes, Ulmus minor, Ulmus pumila.

\section{Introduction}

The genus Ulmus L. (Ulmaceae) comprises approximately 45 woody species, widely distributed throughout the temperate regions of the Northern Hemisphere excluding western North America (Wiegrefe et al., 1994). It is also present in the subtropics in Central America and South-east Asia. The genus and major groups are generally well defined, but detailed delimitation of species and of their taxonomic affinities is very difficult. The reason for this difficulty has been attributed to the shortage of taxonomic traits. This group is characterized by simple and inconspicuous flowers and fruits, highly variable vegetative traits and few barriers to interspecific hybridization. Actually, elms are highly and complexly variable species in terms of their vegetative characters (Richens, 1983). In addition to these, other technical difficulties arise from the concepts used in botanical classification. As a result, the simple determination of the number of species becomes one of the most difficult problems an elm taxonomist can face. Whereas Melville (1978) assumes the existence of

*Correspondence. E-mail: lgil@montes.upm.es

(c) 2000 The Genetical Society of Great Britain. six species in Great Britain alone, Richens (1968) classified all the European elms of the section Ulmus into two species: U. glabra Hudson and U. minor Miller (see Armstrong \& Sell, 1996 for a review of British elms).

These two elm taxa occur naturally in the Iberian Peninsula. The Field elm (U. minor Miller) is distributed in the lowlands of the Spanish territory whereas the Wych elm (U. glabra Hudson) is present in the northern mountain forests. They are the descendants of those populations present after the last glacial period and the introductions that took place in ancient times (Gil \& García-Nieto, 1990). Specifically, Field elms (U. minor Miller sensu lato) have been widely propagated by humans since prehistoric times (Richens, 1983). Partly because of this extensive breeding, it is difficult to determine their natural area. A third species, the exotic Siberian elm ( $U$. pumila L.) was probably introduced in the 16th century as an ornamental tree during Philip II's rule (1556-1598).

The Siberian elm is widely distributed throughout China, Mongolia, Korea and the Asian part of the Russian Federation. It is one of the major tree species for timber, shelter and fodder in eastern Asia. Many European countries introduced it as a gene resource 
for breeding resistance to Dutch elm disease (DED; Lester \& Smalley, 1972; Santamour, 1973; Mittempergher \& La Porta, 1991). In this century, two enormously destructive DED pandemics have spread across Europe and North America. The second to appear was caused by the much more aggressive Ophiostoma novo-ulmi Brasier (Brasier, 1991) and was detected in Spain in the late 1970s. During the 1980s, the Siberian elm's natural resistance to DED made it the most common elm species in both urban and rural areas.

Natural hybridization in the Iberian Peninsula between $U$. pumila from parks, roads and boulevards and $U$. minor produced a large population of hybrid individuals. Their morphological characters appear to be mixed, making difficult any attempt at identification (Ipinza, 1990). Typically, U. pumila shows an open canopy with long, nude branches, where leaves are confined to the end. This gives the tree a weeping appearance that is unlike the round and dense canopy of the native elms. Some other traits related to leaf morphology also make it possible to distinguish between these taxa. Because of the extensive hybridization, conservation of the native genetic resources is a major concern. Since 1990, the Spanish conservation programme has collected and reproduced vegetal material (Solla et al., 2000). To date no data are available regarding the magnitude of the $U$. pumila introgression. Because morphological traits tend to be inaccurate, a more precise tool for the identification of native elms is necessary.

Hybrid identification has been successfully attempted in forest research using isozyme analyses (Schwartz, 1960; Avise, 1974; Fernández, 1996; Hussendörfer, 1999). Isozymatic data of European elms have been previously reported by Pearce \& Richens (1977) and Richens \& Pearce (1984), using only the peroxidase system, and by Machon et al. $(1995,1997)$ using seven enzyme systems. In her earlier study, Machon determined that Ulmus laevis Pallas from section Blepharocarpus produces isozymes that differentiate it from French species of the section Ulmus. Other molecular tools have been reported by Wiegrefe et al. (1994) and Kamalay \& Carey (1995).

In this paper, isozyme profiles of $U$. minor and $U$. pumila are analysed and the results are used to identify hybrids between the species. In the framework of the Spanish programme, the genetic variation of the elm Clonal Bank was also studied in order to guarantee the origin, identity and diversity of the processed material. The ultimate aim was to offer a helpful tool that orients the efforts carried out in the conservation programme of the genetic resources of native elms.

\section{Materials and methods}

The plant material of $U$. minor, $U$. pumila and hybrids used for this study is shown in Table 1. The total sample size was 303 individuals. The samples of $U$. minor consisted of 104 trees. There were 39 trees from the Clonal Bank of the Forest Tree Breeding Centre in Madrid. In this bank, resistant and rare trees from all over Spain are planted. Also 26 trees were sampled from a natural population in the province of Toledo and 39 trees from old plantations in the Royal Gardens in Madrid. The $U$. pumila samples were from two different sources: 46 individuals came from five Chinese populations (Nanyiang, Jiaozue and Shangqiu of the province of Henan, Hueqiu of the province of Anhui, and the city of Beijing) provided by Dr Heybroek in 1989 and planted in La Almoraima (Cádiz). Another 70 U. pumila were taken from different parks in central Spain. Along with these trees, another 83 hybrids between both species were collected. As these trees came from greenhouses and parks, no distinction was made between $\mathrm{F}_{1}$ hybrids and higher-order hybrids. Field determination of species was based on morphological characters proposed by Richens (1968) and Ipinza (1990). Basal asymmetry, petiole length, maximum weight, softness and twists were the major foliar traits used, in addition to the growth habit of the tree, to discriminate between species and between hybrids. In this work, the taxonomic treatment of Richens (1983) based on morphological descriptors is used.

Fully expanded leaf material from mature trees was collected, placed into individual bags, conserved in a portable refrigerator and later stored at $4^{\circ} \mathrm{C}$ until

Table 1 Plant material of Ulmus minor, U. pumila and hybrids

\begin{tabular}{lrcl}
\hline Species & $N^{*}$ & Country & \multicolumn{1}{c}{ Population } \\
\hline Ulmus minor Mill. & 39 & Spain & Elm Gene Bank of \\
& & & CMGF, Madrid \\
& 39 & Spain & Royal Gardens, Madrid \\
& 26 & Spain & Madridejos, Toledo \\
Ulmus pumila L. & 70 & Spain & Urban areas, Madrid \\
& 14 & China & Nanyiang, Henan \\
& 8 & China & Jiaozue, Henan \\
& 7 & China & Shangqiu, Henan \\
& 9 & China & Hueqiu, Anhui \\
& 8 & China & The city of Beijing \\
Hybrids & 83 & Spain & Urban areas, central \\
Total & & & Spain \\
\hline
\end{tabular}

* sample size. 
enzyme extraction. For the enzyme extraction, $3.5 \mathrm{~cm}^{2}$ of leaf was homogenized at $4^{\circ} \mathrm{C}$ for $30 \mathrm{~s}$ with $550 \mu \mathrm{L}$ of extraction buffer, modified from Afzal-Rafii (1988). After centrifugation (7000 r.p.m. for $10 \mathrm{~min}$ ) extracts were stored at $-75^{\circ} \mathrm{C}$ until used for electrophoresis. The whole process was completed in less than $36 \mathrm{~h}$.

Aspartate amino transferase, AAT (EC 2.6.1.1), anodic peroxidase, PRX (EC 1.11.1.7), phosphoglucoisomerase, PGI (EC 5.3.1.9), leucine amino peptidase, LAP (EC 3.4.11.1), catalase, CAT (EC 1.11.1.6) and acid phosphatase, ACPH (EC 3.1.3.2) were resolved using a lithium-borate electrode and gel buffer adapted from Shaw \& Prasad (1970). Isocitrate dehydrogenase, IDH (EC 1.1.1.41), malate dehydrogenase, MDH (EC 1.1.1.37) and 6-phosphogluconate dehydrogenase, 6PGD (EC 1.1.1.44) were resolved using a morpholine gel and buffer adapted from Wendel \& Weeden (1989). Staining procedures and electrophoretic methods were adapted from Cheliak \& Pitel (1984) and Acquaah (1992). Gels of PRX for $U$. minor were read and photographed 5 min after being placed in the warming oven to avoid lagged bands that complicate the interpretation. Loci and alleles were named according to their relative position in the gel, denoting the most anodal by 1 .

To confirm the genetic control of the electrophoretic patterns the offspring of two controlled crosses with more than 10 seedlings each were analysed. Chi-squared analysis of expected and observed number of genotypes per locus was performed.

Genetic data were analysed using version 1.31 of the POPGENE program (Yeh et al., 1997). The genotypic diversity ( $v$, Gregorius, 1978) and the total population differentiation $\left(\delta_{\mathrm{T}}\right.$, Gregorius, 1987) were computed for each taxon and for the multilocus genotype using the GSED program (Gillet, 1998). Nei's (1973) genetic distances among species were computed taking every locus into consideration. Cluster analyses were performed using the unweighted pair group method algorithm (UPGMA).

Canonical discriminant analysis of all polymorphic loci was performed using the sAS program (SAS, 1982). Class membership was defined for four groups: $U$. pumila from China, U. pumila from Spain, U. minor and hybrids. Isozyme profiles of trees were coded not only as alleles but also as genotypes following the method outlined by Smouse \& Neel (1977). The variables generated are similar to binomial variables and result in a normal distribution for a sufficiently large amount of data. For example, consider a locus with two alleles $A$ and $B$ and therefore with three possible genotypes $A A, A B$ and $B B$. This locus can be translated by one variable with values $1,0.5$ and 0 for each genotype, respectively. This way, for each single locus with $n$ alleles this method generates $(n-1)$ variables.

\section{Results}

The nine enzyme systems studied are encoded by 13 loci. Five enzyme systems (AAT, IDH, ACPH, CAT and LAP) are encoded only by one locus, whereas PGI, 6PGD, MDH and PRX reveal two loci. In addition, PRX has one cathodal locus, which is not included in this work. Enzyme bands and phenotypes for enzyme systems are presented in Fig. 1. Most systems (AAT, 6PGD, IDH, ACPH, MDH and PGI) showed typical dimeric patterns (one or three bands) and only three (CAT, LAP and PRX) showed a monomeric pattern. Chi-squared analyses of observed and expected genotypes from the controlled crosses demonstrated no significant deviation between observed and expected Mendelian ratios at the 0.05 level (Table 2). The loci Idh, 6Pgd2, Mdh1, Prx2 and Pgi2 segregated successfully. There was no reason to reject the general hypotheses that these elm species were diploid and that isozymes had a codominant inheritance.

Allele frequencies are shown in Table 3. A total of 16 alleles (10 in $U$. pumila and six in $U$. minor) were observed to belong exclusively to one of either species (Table 4). The so-called species-specific gene markers provide the information needed to classify a tree. These alleles were distributed at seven loci, but the most frequent ones appeared at five of them: $6 \operatorname{Pgd} 2, \operatorname{Pr} x 2$, Mdh1, Acph and Aat. The first three systems, 6Pgd2, $\operatorname{Pr} x 2$ and $M d h 1$ completely discriminated between both species. Differences between the two U. pumila groups can also be reported. There were three low-frequency alleles (Aat-2, Prx2-n and Pgi2-4) of Chinese Siberian elm that were not present in the Spanish populations. There are also two alleles (Mdh2-3 and Pgi2-3) which showed greatly reduced frequencies. In contrast, alleles Idh-4 and Mdh2-1 appeared only in the Siberian elm from Spain. The dendrogram based on Nei's (1973) genetic distances, performed using the UPGMA method algorithm, locates putative hybrids between both species and U. pumila at a distance of 1.97 units (Fig. 2). The other cluster, consisting only of the $U$. minor group, is separated at a distance of 16.51 units.

In addition to the allele frequency distribution, the genotypic structure was analysed. Genotypes of the hybrids were checked to detect individuals that share species-specific alleles of each species. As a result, hybrids were divided into two groups: those with specific alleles of both species $(77.1 \%)$ and those with only specific alleles of $U$. pumila $(20.5 \%)$. Among the hybrids, no trees were found to have only $U$. minor specific alleles. The remaining $2.4 \%$ could not be identified because of missing scores.

Seven of the 13 loci analysed (54\%) were polymorphic in U. minor, $10(77 \%)$ in U. pumila and $11(85 \%)$ in the 


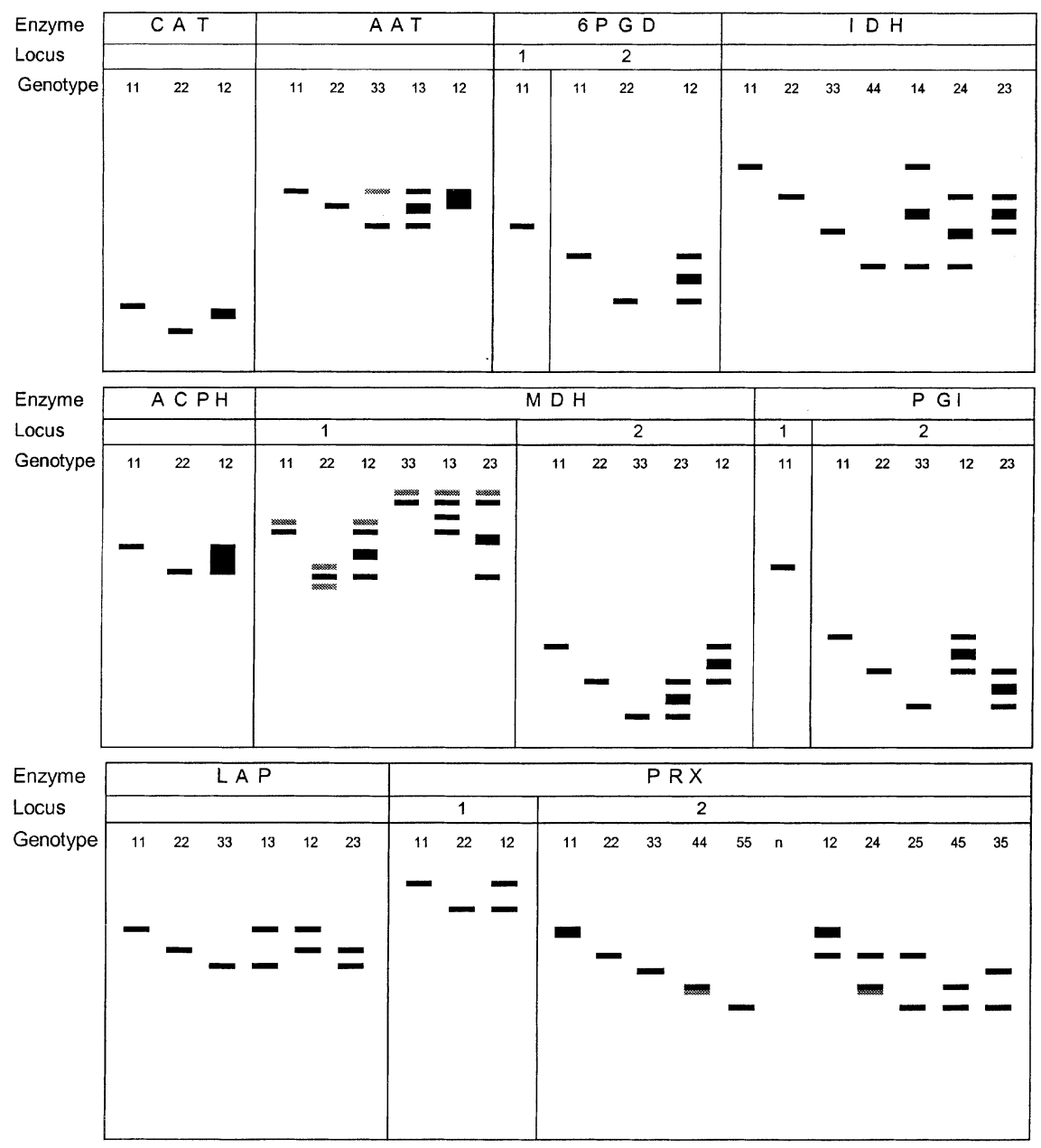

Fig. 1 Enzyme phenotypes for six loci of Ulmus minor, $U$. pumila and hybrids. Intensity and thickness of the band resemble those on gels. $n$, null allele. hybrids (Table 5). The average number of alleles per locus was similar in both species, 1.4 and 1.5 in $U$. minor and $U$. pumila, respectively. In the hybrids the average number of alleles per locus was 1.8. Hybrids had a higher mean observed heterozygosity $\left(H_{\mathrm{o}}\right)$ than individuals from the parental species and their genotypic diversity $(v)$ was intermediate between them. The hybrids had a remarkably high degree of heterozygosity: $50 \%$ of them showed more than four heterozygous loci. Of the Chinese and Spanish U. pumila populations, $11 \%$ and $8 \%$, respectively, reached this degree of heterozygosity. In the case of $U$. minor, only $5 \%$ did so.

Two significant $(P<0.001)$ canonical discriminant functions accounted for $99 \%$ of the total variance. The first canonical discriminant function accounted for $95 \%$ of the total variance, $94 \%$ of which was explained by the groups' contribution. This function is dominated by a large loading from $6 \mathrm{Pgd} 2$. In order to get positive values for this function, trees had to score high on $6 P g d 2$ and low on $M d h 1$. The second canonical discriminant function had high coefficients for Mdh2, Pgi2 and
Prx2. Plotting the groups for the two canonical functions, $U$. minor appeared in an extended area widely separated from $U$. pumila (Fig. 3). There is a clear overlap of the areas corresponding to the Siberian elms from China and those from Spain. Hybrids with specific alleles of both species are in an intermediate position, whereas the area of hybrids with only $U$. pumila specific alleles overlaps with that of $U$. pumila.

\section{Discussion}

\section{Genetic interpretation of isozyme patterns}

Genetic interpretation of electrophoretic patterns is not without controversy. Feret \& Stairs (1971) and Feret (1972), who studied the inheritance of the PRX system in the Siberian elm, found unexpected phenotypes among hybrids. Although they speculated with partial incompatibility among elm homologues, they finally concluded that peroxidase inheritance in Siberian elm was controlled by a one-locus, three-allele genetic 
Table 2 Segregation in Ulmus. Genotypes of parent trees and offspring of two families

\begin{tabular}{|c|c|c|c|c|c|c|c|}
\hline \multirow[b]{2}{*}{ Locus } & \multirow[b]{2}{*}{ Cross } & \multicolumn{2}{|c|}{ Parental genotypes } & \multirow{2}{*}{$\begin{array}{l}\text { Offspring } \\
\text { genotypes }\end{array}$} & \multirow[b]{2}{*}{ Expected } & \multirow[b]{2}{*}{ Observed* } & \multirow[b]{2}{*}{$N$} \\
\hline & & Female & Male & & & & \\
\hline$I d h$ & $\mathrm{MP} 1 \times \mathrm{P} 1$ & 23 & 22 & $\begin{array}{l}22 \\
23\end{array}$ & $\begin{array}{l}19.5 \\
19.5\end{array}$ & $\begin{array}{l}17 \\
22\end{array}$ & 39 \\
\hline $6 P g d 2$ & $\mathrm{MP} 1 \times \mathrm{P} 1$ & 12 & 22 & $\begin{array}{l}12 \\
22\end{array}$ & $\begin{array}{l}16.5 \\
16.5\end{array}$ & $\begin{array}{l}17 \\
16\end{array}$ & 33 \\
\hline$M d h 1$ & $\mathrm{MP} 2 \times \mathrm{MP} 3$ & 33 & 12 & $\begin{array}{l}11 \\
12 \\
13 \\
23 \\
13 \\
33\end{array}$ & $\begin{array}{l}9.5 \\
9.5 \\
9.5 \\
9.5 \\
4.5 \\
4.5\end{array}$ & $\begin{array}{r}13 \\
6 \\
11 \\
8 \\
3 \\
6\end{array}$ & 38 \\
\hline $\operatorname{Pr} x 2$ & $\mathrm{MP} 2 \times \mathrm{MP} 3$ & 23 & 11 & $\begin{array}{l}23 \\
24 \\
34 \\
44 \\
12 \\
13\end{array}$ & $\begin{array}{l}7.5 \\
7.5 \\
7.5 \\
7.5 \\
3 \\
3\end{array}$ & $\begin{array}{l}8 \\
8 \\
7 \\
7 \\
4 \\
2\end{array}$ & 30 \\
\hline Pgi2 & $\mathrm{MP} 2 \times \mathrm{MP} 3$ & 13 & 13 & $\begin{array}{l}11 \\
13 \\
33\end{array}$ & $\begin{array}{l}2.5 \\
5 \\
2.5\end{array}$ & $\begin{array}{l}3 \\
3 \\
4\end{array}$ & 10 \\
\hline
\end{tabular}

P1, Ulmus pumila; MP1, MP2 and MP3, U. minor $\times U$. pumila. $N$, sample size of the offspring.

*Chi-squared analysis of all expected and observed genotypes demonstrated no significant deviation at the 0.05 level.

system. One of the hypotheses they subtly pointed out to explain aberrant rates in segregation of $U$. pumila and $U$. rubra hybrids was that genes were not allelic but were instead located on two homologous chromosomes at different loci. In this case, crossing over between the two loci could produce gametes containing either both genes or neither gene. A similar phenomenon has already been described by Gottlieb (1982) for diploid species of Clarkia (Onagraceae). Recently, Machon et al. (1995) suggested that elms were segmental allotetraploids and that they behaved as tetraploids for part of the genome and as diploids for the rest. In the present study, phenotypes of the $P R X$ system in $U$. minor present two bands similar to those observed by Richens \& Pearce (1984). All electrophoretic patterns were interpreted as diploids according to Feret \& Stairs (1971). Segregation ratios validate these inheritance models.

\section{Genetic differences between taxa}

Genetic differences have been found between the parental species. Evidence from this study supports the hypothesis that each species possesses its own allele distribution as well as its own species-specific alleles.
A null allele at $\operatorname{Pr} x 2$ for Siberian elm was previously reported by Feret \& Stairs (1971) and by Feret (1972). In the present work it was only detectable in the homozygous state. Therefore, in the hybrid group it could be present in the heterozygous state. In regard to $U$. minor, there are no references to this allele (Richens \& Pearce, 1984; Machon et al., 1995, 1997). Discriminant analyses of isozyme profiles provide a reliable tool to distinguish $U$. pumila and hybrids from the native Field elm. Some differences between these taxa have been previously reported by Heimler et al. (1993) using flavonoid glycoside data. Isozyme species-specific alleles have also been found belonging to $U$. minor and $U$. laevis (Machon et al., 1995), where hybridization is very rare.

The maintenance of sexual reproduction for $U$. pumila produces a high rate of single- and multilocus genetic diversity $\left(H_{\mathrm{T}}\right.$ and $\left.v\right)$ similar to those of outcrossing and wind-pollinated plants (Hamrick \& Godt, 1989). The lowest rates of all measures of genetic diversity are those of $U$. minor (in particular, $H_{\mathrm{T}}=0.19$ ) where successful sexual reproduction is very rare. In contrast, the genetic diversity of $U$. minor according to French studies is $H_{\mathrm{T}}=0.34$ (Machon et al., 1997) with a $100 \%$ rate of polymorphic loci. These results are not contradictory, 
Table 3 Allele frequencies for all loci of Ulmus minor, U. pumila and their hybrids

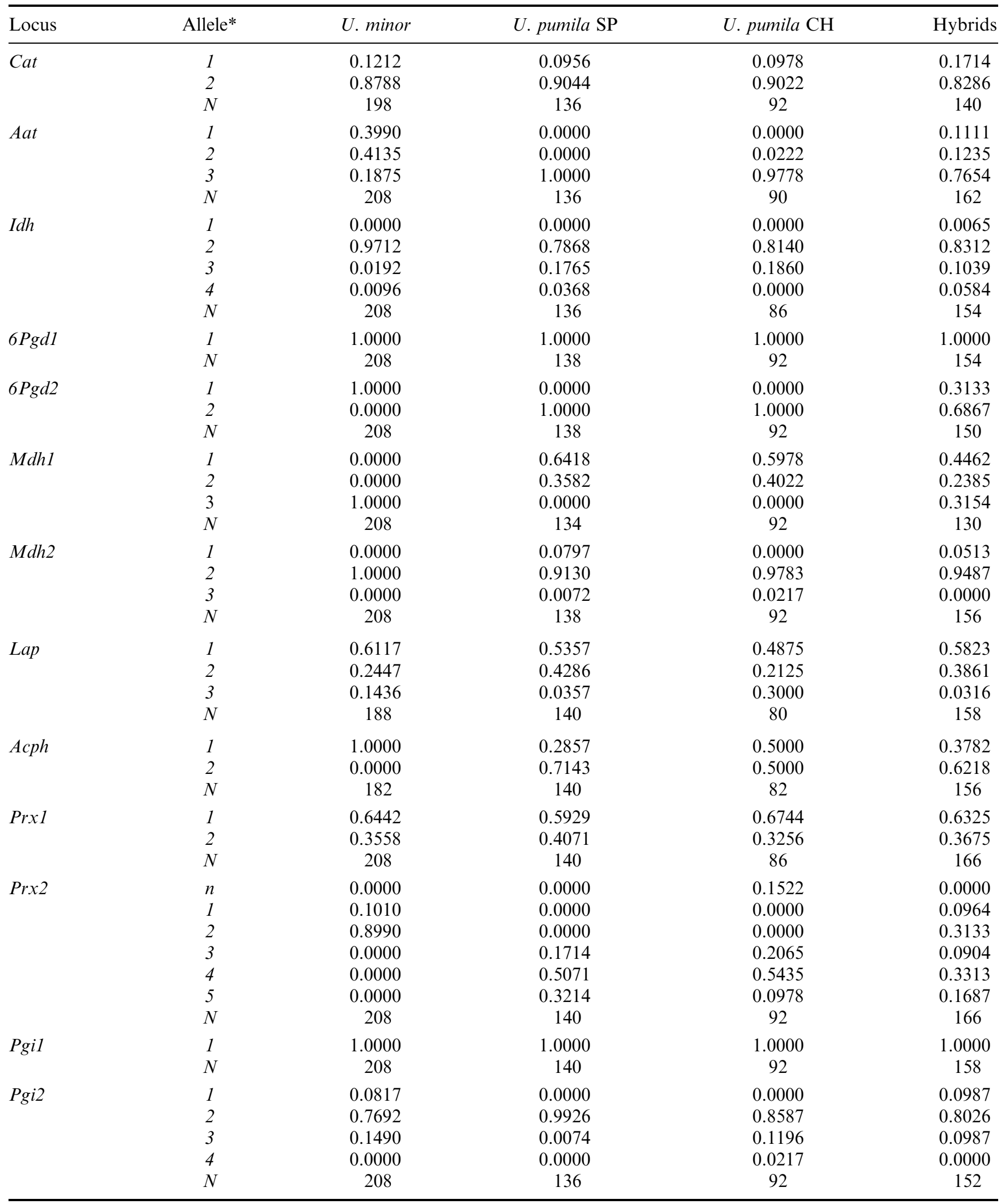

SP, Spanish populations; $\mathrm{CH}$, Chinese populations; $n$, null allele.

*Also $N$, sample size.

(c) The Genetical Society of Great Britain, Heredity, 85, 157-166. 
in fact, the genetic diversity found in this study taking only polymorphic loci into consideration gives similar values $\left(H_{\mathrm{T}}=0.35\right.$, if $\left.P=100 \%\right)$.

Table 4 Diagnostic loci between Ulmus minor, U. pumila and hybrids

\begin{tabular}{lccc}
\hline Locus & Allele & Designation & Frequency \\
\hline Acph & 2 & $\mathrm{P}$ & 0.71 \\
Prx2 & $n$ & $\mathrm{P}$ & 0.15 \\
& 1 & $\mathrm{M}$ & 0.10 \\
& 2 & $\mathrm{M}$ & 0.90 \\
& 3 & $\mathrm{P}$ & 0.17 \\
& 4 & $\mathrm{P}$ & 0.51 \\
& 5 & $\mathrm{P}$ & 0.32 \\
Pgi2 & 1 & $\mathrm{M}$ & 0.08 \\
6Pgd2 & 1 & $\mathrm{M}$ & 1.00 \\
& 2 & $\mathrm{P}$ & 1.00 \\
Mdh1 & 1 & $\mathrm{P}$ & 0.63 \\
& 2 & $\mathrm{P}$ & 0.36 \\
\multirow{3}{*}{ Mdh2 } & 3 & $\mathrm{M}$ & 1.00 \\
& 1 & $\mathrm{P}$ & 0.08 \\
Aat & 3 & $\mathrm{P}$ & 0.01 \\
\hline & 1 & $\mathrm{M}$ & 0.39 \\
\hline
\end{tabular}

M, Ulmus minor; $\mathrm{P}$, Ulmus pumila; $n$, null allele.

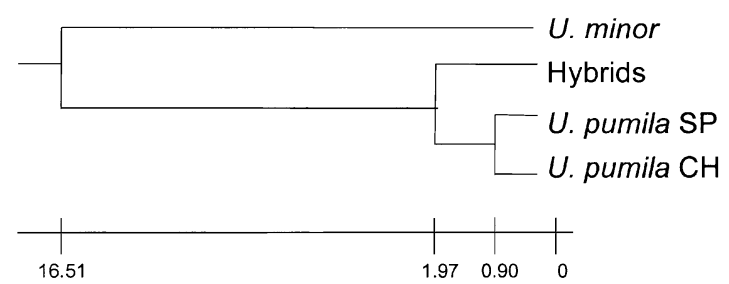

Fig. 2 Dendrogram of UPGMA cluster analysis based on Nei's genetic distances between Ulmus minor and U. pumila. SP, Spanish populations; $\mathrm{CH}$, Chinese populations.
Spanish and Chinese $U$. pumila are very similar. In Fig. 3 it can be observed that the Spanish population area is almost contained within the Chinese one. In addition, the Chinese population exhibits equal or higher mean values for all measures of diversity compared to Spanish populations. But differences also exist in some lowfrequency alleles. This situation could be explained in two ways. First, prior differences may have existed between Chinese $U$. pumila and those types that were effectively introduced into Spain. It is possible that Siberian elms had already been introduced into the Iberian Peninsula in the 16th century from Russia. As trees, plants and gardens were a major concern for Philip II, the ambassadors sent all kinds of exotic trees from their countries to the Royal Court (Gil \& García-Nieto, 1990). So, it is probable that the introduction that took place in modern times was, in fact, a reintroduction. A second explanation for this situation is that a founder effect could have been the result of the reduction in the population size when the Siberian elm was introduced in Spain.

\section{Nature of hybridization}

Taking account of both the allele distributions and the genetic distances, a highly asymmetrical pattern of hybridization is revealed. Hybrids appear to be nearer to $U$. pumila than $U$. minor. Asymmetric hybridization has already been described in a mixed stand of European oaks (Bacilieri et al., 1996). In the framework of selection of DED resistant clones, hybridization studies are common practice (Lester \& Smalley, 1972; Santamour, 1973; Mittempergher \& La Porta, 1991). Crossing trials determined that $U$. minor and $U$. pumila can crossbreed freely and produce fertile hybrids. So it is unlikely that random effects alone can explain these results. This situation could be explained because backcrossing occurs more frequently with Siberian elm. Particularly, the percentage of full seeds from pollinated flowers is $31.3 \%$ if $U$. minor is the female

Table 5 Genetic diversity for 13 loci in elms

\begin{tabular}{|c|c|c|c|c|c|c|c|}
\hline & \multirow[b]{2}{*}{$N$} & \multirow[b]{2}{*}{$\mathrm{P}(\%)$} & \multicolumn{3}{|c|}{ Single locus } & \multicolumn{2}{|c|}{ Multilocus } \\
\hline & & & $n_{\mathrm{e}}$ & $H_{\mathrm{o}}$ & $H_{\mathrm{T}}$ & $v$ & $\delta_{\mathrm{T}}$ \\
\hline U. minor & 204 & 53.8 & 1.38 & 0.22 & 0.19 & 17.58 & 0.955 \\
\hline U. pumila SP & 138 & 69.2 & 1.46 & 0.22 & 0.24 & 61.06 & 0.999 \\
\hline U. pumila $\mathrm{CH}$ & 89 & 76.9 & 1.55 & 0.22 & 0.27 & 33.11 & 0.998 \\
\hline Hybrids & 154 & 84.6 & 1.79 & 0.34 & 0.32 & 49.00 & 1.000 \\
\hline
\end{tabular}

Ulmus pumila: $\mathrm{SP}$, Spanish populations; $\mathrm{CH}$, Chinese populations.

$N$, mean sample size per locus; P, percentage of loci polymorphic; $n_{\mathrm{e}}$, mean effective number of alleles per locus; $H_{\mathrm{o}}$, mean observed heterozygosity; $H_{\mathrm{T}}$, Nei's genetic diversity calculated considering every locus; $v$, genotypic diversity; $\delta_{\mathrm{T}}$, population differentiation. 


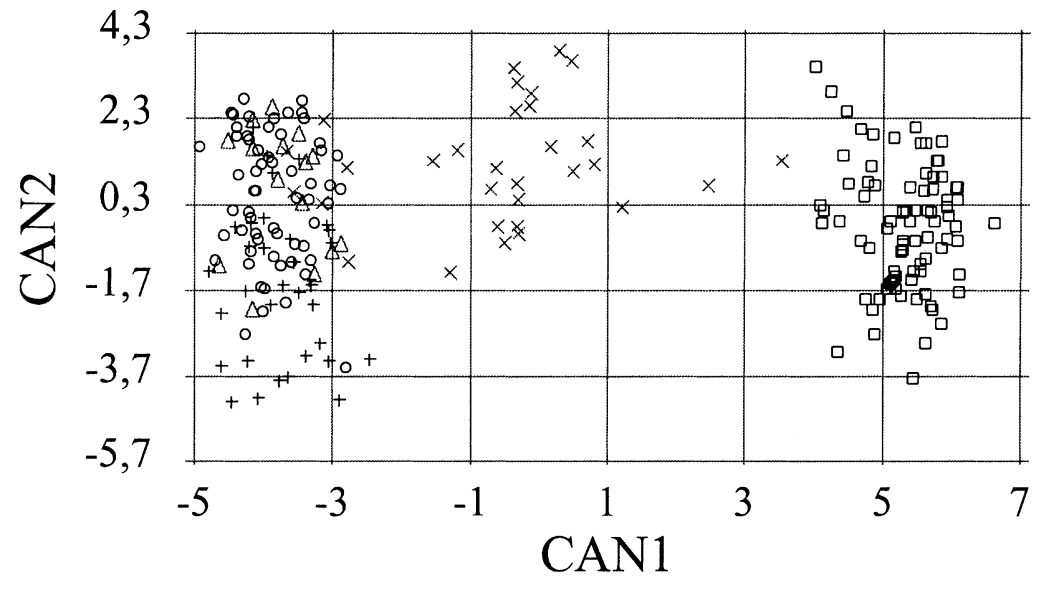

Fig. 3 Plot of first canonical discriminant function, CAN1, vs. second canonical discriminant function, CAN2. $\square$, Ulmus minor; $\bigcirc, U$. pumila from Spain; +, U. pumila from China; $\times$, hybrids with specific alleles of both species; $\triangle$, hybrids with specific alleles only of $U$. pumila. parent and $47.2 \%$ otherwise (Mittempergher \& $\mathrm{La}$ Porta, 1991). Furthermore, in natural conditions, reproduction in $U$. minor is normally vegetative by root suckers and seed is only set in rare, especially favourable, seasons (Richens, 1983). In U. pumila, on the other hand, reproduction is normally by seeds (Chang Geng, 1989). These results reveal a different mating behaviour between species, which is one of the hypotheses that could explain the preferential backcrossing of the hybrids with $U$. pumila.

This asymmetric hybridization may also be generated by different spatial or temporal distributions of adult tree genotypes and, as a consequence, of pollen pool genotypes (Brown et al., 1985). The hybridization process occurs frequently in urban areas, where $U$. pumila has been more abundant in recent decades. Because many populations contain hybrids, and U. pumila, but rarely $U$. minor, backcrossing occurs with Siberian elms, giving a range of possible intermediates. This could explain why some hybrids lack specific alleles of $U$. minor, which cannot be differentiated by isozymes from $U$. pumila. Another case of backcrossing in hybrids of these species was described in Kazakhstan and the Volga and Ural regions of the USSR by Knyazeva \& Knyazeva (1986). In that study, a morphological analysis of leaves of $U$. pumila and $U$. minor showed a hybrid origin of $U$. pumila in shelterbelt trials.

Significantly greater values of $H_{\mathrm{T}}$ were observed in the hybrids, up to $60 \%$ greater than in the parental taxa. This increase in heterozygosity is greater than that observed in a hybrid population of Aesculus $(40 \%$ in dePamphilis \& Wyatt, 1990). Hybrids accumulate alleles of both parental species. Moreover, hybridization in Ulmus appears to create new combinations of alleles, rather than simply to increase heterozygosity at already polymorphic loci, as seen in Aesculus.

In conclusion, this study demonstrates a helpful tool for the genetic conservation programmes of the Euro- pean elm. Ulmus minor produces isozyme patterns which differentiate it from $U$. pumila and from their hybrids. Hence, isozyme markers can be used, not only to characterize, but also to distinguish native elms from hybrids that have evolved for generations. It is noticeable that backcrossing results in a hybrid population genetically closer to $U$. pumila than to $U$. minor. New isozyme genes, controlling the PRX, MDH and 6PGD systems, are also described and they are shown to be marker genes for $U$. minor and $U$. pumila. In addition, the AAT, ACPH, IDH and LAP systems are described for the first time in European elms. Finally, it is emphasized that Spanish U. minor did not show any of the specific alleles of $U$. pumila. This is a goal for conservation programmes, and confirms that conservation of native elm genetic resources is still possible.

\section{Acknowledgements}

We would like to thank Dr Ricardo Alía and Santiago C. González for helpful statistical advice and encouragement. Thanks to Dr Cipriano Aragoncillo for an early review of the paper and his valuable suggestions. We also thank Salustiano Iglesias, $\mathbf{M}^{\mathrm{a}}$ Carmen García and Margarita Burón for their technical assistance. Finally, we thank José Ignacio Cogolludo and Mireya García for their assistance reviewing the English manuscript. The study was supported by funds from the DGCONA (Ministry of Environment) and the EU Project RESGEN CT 96-78.

\section{References}

ACQuAAH, G. 1992 Practical Protein Electrophoresis for Genetic Research. Dioscorides Press, Portland, OR.

AFZAL-RAFII, Z. 1988. Caractéristiques taxonomique, morphologique et isoenzymatique du complexe 'Chêne vert'. Bull. Soc. Bot. Fr. Lettres Bot., 135, 343-352. 
ARMSTRONG, J. V. AND SELL, P. D. 1996. A revision of the British elms (Ulmus L., Ulmaceae): the historical background. Bot. J. Linn. Soc., 120, 39-50.

AVISE, J. C. 1974. Systematic value of electrophoresis data. Syst. Zool., 23, 465-481.

BACILIERI, R., DUCOUSSO, A., PETIT, R. J. AND KREMER, A. 1996. Mating system and asymmetric hybridization in a mixed stand of European oaks. Evolution, 50, 900-908.

BRASIER, C. M. 1991. Ophiostoma novo-ulmi sp. nov., causative agent of the current Dutch elm disease pandemics. Mycopathologia, 115, 151-161.

BROWN, A. H. D., BARRET, S. C. H. AND MORAN, G. F. 1985. Mating system estimation in forest trees: Models, methods and meanings. In: Gregorius, H. R. (ed.) Populations Genetics in Forestry, pp. 32-49. Springer, Berlin.

CHANG GENG, M. 1989. A provenance test of white elm (Ulmus pumila L.) in China. Silvae Genet., 38, 37-44.

CHELIAK, W. M. AND PITEL, J. A. 1984. Techniques for Starch Gel Electrophoresis of Enzymes from Forest Trees. Information Report Petawawa National Forestry Institute, PI-X-42. Canadian Forestry Service.

DEPAMPHILIS, C. W. AND WYATT, R. 1990. Electrophoretic confirmation of interspecific hybridization in Aesculus (Hippocastanaceae) and the genetic structure of a broad hybrid zone. Evolution, 44, 1295-1317.

FERET, P.P. 1972. Peroxidase isozyme variation in interspecific elm hybrids. Can. J. Forest Res., 2, 264-270.

FERET, P.P. AND STAIRS, R. G. 1971. Peroxidase inheritance in Ulmus pumila L. Forest Sci., 17, 472-475.

FERNÁNDEZ, J. 1996. Variabilidad Isoenzimática y Selección Clonal en Castanea sativa Miller, C. crenata. Sieb. et Zucc., C. mollissima Blume e Hibridos Interespecificos. PhD Thesis, E.T.S.I. Montes, Madrid.

GIL, L. AND GARCíA-NIETO, M. E. 1990. Paleobotánica e historia de los olmos de la Península Ibérica. In: Gil, L. (ed.) Los Olmos Y la Grafiosis En España, pp. 29-65. ICONA, Madrid.

GILLET, E. M. 1998. GSED. Genetic structures from electrophoretic data. User's manual, version 1.1e. Abteilung für Forstgenetik und Forstpflanzenzüchtung der Universität Göttingen.

GOTTLIEB, L. D. 1982. Conservation and duplication of isozymes in plants. Science, 216, 373-380.

GREGORIUS, H. R. 1978. The concept of genetic diversity and its formal relationship to heterozygosity and genetic distance. Math. Biosci., 41, 253-271.

GREGORIUS, H.-R. 1987. The relationship between the concepts of genetic diversity and differentiation. Theor. Appl. Genet., 74, 397-401.

HAMRICK, J. L. AND GODT, M. J. W. 1989. Allozyme diversity in plant species. In: Brown, A.H.D., Clegg, M.T., Kahler, A.L., and Weir, B.S. (eds) Plant Population Genetics, Breeding, and Genetic Resources, pp. 43-63. Sinauer, Sunderland, MA.

HEIMLER, D., PIERONI, A., MITTEMPERGHER, L. AND BUZZINI, P. 1993. The use of flavonoid glycosides for the identification of elm hybrids. Can. J. Forest Res., 23, 611-616.

HUSSENDÖRFER, E. 1999. Identification of natural hybrids Juglans x intermedia Carr. using isoenzyme gene markers. Silvae Genet., 48, 50-52.
IPINZA, R. 1990. Algunos aspectos relevantes sobre la taxonomía de los olmos ibéricos. In: Gil, L. (ed.) Los Olmos Y la Grafiosis En España, pp. 69-96. ICONA, Madrid.

KAMALAY, J. C. AND CAREY, D. W. 1995. Application of RAPDPCR markers for identification and genetic analysis of American elm (Ulmus americana L.) selections. J. Envir. Hort., 13, 155-159.

KNYAZEVA, L. A. AND KNYAZEVA, L. A. 1986. Morphological analysis of the leaves of Siberian elm and Field elm. In: Tokarev, A. D., Bespalov, V. P., Polyakova, G. A., Inevatov, S. E. and Knyazeva, L. A. (eds) Biogeotsenoticheskie Issledovaniya Iskusstvennykh Nasazhdenii V Zasushlivoi Stepi Zapadnogo Kazakhstana [Ecosystem Studies on Plantations in the Arid Steppe of Western Kazakhstan], pp. 27-70. Nauka, Moscow. (In Russian with English summary).

LESTER, D. H. AND SMALlEY, E. B. 1972. Improvement of elms through interspecific hybridization with Asian species. In: Proc. IUFRO Genetics-Sabrao Joint Symposia. C-5 V, pp. 1-10. Tokyo, Japan.

MACHON, N., LEFRANC, M., BILGER, I. AND HENRY, J. P. 1995. Isoenzymes as an aid to clarify the taxonomy of French elms. Heredity, 74, 39-47.

MACHON, N., LEFRANC, M., BILGER, I., MAZER, S. J. AND SARR, A. 1997. Allozyme variation in Ulmus species from France: analysis of differentiation. Heredity, 78, 12-20.

MELVILLE, R. 1978. On the discrimination of species in hybrid swarms with special reference to Ulmus and the nomenclature of Ulmus minor Mill. and U. carpinifolia Gled. Taxon, 27, 345-351.

MITTEMPERGHER, L. AND LA PORTA, N. 1991. Hybridization studies in the Eurasian species of elms (Ulmus spp.). Silvae Genet., 40, 237-243.

NEI, M. 1973. Analysis of gene diversity in subdivided populations. Proc. Natl. Acad. Sci. U.S.A., 70, 33213323.

PEARCE, N. J. AND RICHENS, R. H. 1977. Peroxidase isozyme in some elms (Ulmus L.) of eastern England. Watsonia, 11, 382-383.

RICHENS, R. H. 1968. The correct designation of the European Field elm. Feddes Repertorium, 79, 1-2.

Richens, R. H. 1983. Elm. Cambridge University Press. Cambridge.

RICHENS, R. H. AND PEARCE, N. J. 1984. Isoperoxidase variations in Ulmus L. Forestry, 57, 75-84.

SANTAMOUR, F. S., JR. 1973. Resistance to Dutch elm disease in Chinese elm hybrids. Plant Dis. Reptr., 57, 997-999.

SAS 1982. SAS User's Guide: Statistics. SAS Institute, Inc., Cary, NC.

SCHWARTZ, D. 1960. Genetic studies on mutant enzymes in maize. Synthesis of hybrid enzymes by heterozygotes. Proc. Natl. Acad. Sci. U.S.A., 46, 1210-1215.

SHAW, C. R. AND PRASAD, R. 1970. Starch gel electrophoresis of enzymes. A compilation of recipes. Biochem. Genet, $\mathbf{4}$, 297-320.

SMOUSE, P. E. AND NEEL, J. V. 1977. Multivariate analysis of gametic disequilibrium in the Yanomama. Genetics, 85, 733-752. 
SOLLA, A., MENÉNDEZ, Y., BURÓN, M., IGLESIAS, S. AND GIL, L. 2000. Spanish Program for the Conservation and Breeding of Elms Against DED. In: Dunn, C. P. (ed.) The Elms: Breeding, Conservation and Disease Management, pp. 295-303. Kluwer Academic Publishers, Boston/Dordrecht/London.

WENDEL, J. F. AND WEEDEN, N. F. 1989. Isozymes in Plant Biology. Dioscorides Press, Portland, OR.
WIEGREFE, S. J., SYTSMA, K. J. AND GURIES, R. P. 1994. Phylogeny of elms: molecular evidence for a sectional classification. Syst. Bot., 19, 590-612.

YEH, F. C., YANG, R. C. AND BOYLE, T. 1997. POPGENE, version 1.21. University of Alberta. 